\title{
FACTORS CAUSING DISCRIMINATION AGAINST WOMEN IN THE AL- BERZANJI ROUTINE IN KROMASAN VILLAGE, TULUNG AGUNG REGENCY, EAST JAVA
}

\author{
Ahmad Sugeng Riady \\ Mahasiswa Sosiologi Agama, UIN Sunan \\ Kalijaga Yogyakarta \\ Email: ahmadsugengriady@gmail.com
}

\begin{abstract}
The research objective is to describe factors causing discrimination against women in Al-Berzanji routine in Kromasan Village, Tulungagung Regency, East Java. Descriptive qualitative research design was used in the research. There were two data sources in the research namely primary and secondary data. The research findings showed that the causes of women's discrimination in the Al-Berzanji routine were divided into internal and external factors. Internal factors are negative evaluations of women, restrictions on women's religious expression, and the feeling of less empowered. While external factors are patriarchal culture and less proper education got by women.
\end{abstract}

Abstrak : Penelitian ini membahas tentang perempuan di dalam rutinan Al-Berzanji di Desa Kromasan, Kabupaten Tulungagung, Jawa Timur. Penelitian ini fokus pada penyebab yang membuat perempuan didiskriminasi dalam rutinan Al-Berzanji. Adapun metode yang digunakan di dalam penelitian ini yakni deskriptif-kualitatif dengan sumber data primer dan sekunder. Penelitian ini menemukan bahwa penyebab diskriminasi perempuan dalam rutinan AlBerzanji dibedakan menjadi faktor internal dan eksternal. Faktor internal meliputi penilaian negatif terhadap perempuan, pembatasan ekspresi keberagamaan perempuan, dan perempuan sendiri merasa kurang berdaya. Sedangkan faktor eksternal meliputi budaya patriarki yang masih mengakar kuat dan perempuan kurang mendapatkan pendidikan yang layak.

Keywords: External and Internal Factors, Women Discrimination, and Al-Berzanji Routine 
AGENDA : Analisis Gender dan Anak,Vol. 3 (2), 2021, (Desember)

ISSN Print: $\underline{2615-1502}$

ISSN Online: $\underline{2723-3278}$

Tersedia online di

http://ecampus.iainbatusangkar.ac.id/ojs/index.php/agenda

\section{PENDAHULUAN}

Sejarah gender dimulai pada tahun 1970an. Istilah tersebut digunakan oleh kalangan feminis barat untuk membedakan antara gender dan sex. Karena menurut feminis barat, tidak ada kaitannya antara perbedaan fisik antara laki-laki dan perempuan dengan sifat sekaligus peran antara laki-laki dan perempuan di masyarakat. Bahkan sebelum abad ke 18, jenis kelamin manusia dianggap hanya satu. Thomas Laquer dalam bukunya yang berjudul Making Sex: Body and Gender from the Greeks to Freud mengatakan bahwa pada dasarnya, jenis kelamin antara laki-laki dan perempuan itu sama. Baru pada abad selanjutnya muncullah perkembangan dari ilmu kedokteran yang membedakan secara jelas anatomi antara jenis kelamin laki-laki dan perempuan. ${ }^{1}$

Gender berbeda dengan jenis kelamin. Meskipun dalam Bahasa Inggris dan Kamus Ilmiah Populer, gender diartikan sama dengan jenis kelamin. ${ }^{2}$ Tapi sebenarnya kedua istilah -gender dan jenis kelamin- itu memiliki perbedaan. Jenis

\footnotetext{
${ }^{1}$ Katrin Bandel, Kajian Gender Dalam Konteks Pascakolonia (Yogyakarta : Sanata Dharma University Press, 2016), hlm. 38

2 Tim Prima Pena, Kamus IImiah Populer (Gitamedia Press, 2006), hlml. 149.
}

kelamin merupakan pembagian kelamin manusia yang didasarkan pada sisi biologis, sifatnya kodrati. Misalnya lakilaki mempunyai penis, sedangkan perempuan mempunyai payudara, hamil, dan bisa menyusui. Sedangkan gender merupakan sifat yang melekat pada manusia. Sifat ini biasanya telah dikonstruksikan oleh sosial-budaya di lingkungan masyarakat setempat. Misalnya laki-laki dianggap lebih kuat dari perempuan, perempuan mempunyai sifat yang lembut dan emosional, perempuan tidak boleh keluar sampai larut malam, dan seterusnya. $^{3}$

Jika melihat sejarah di tanah Arab sebelum Agama Islam datang, perempuan belum dianggap sebagai manusia seutuhnya. Misalnya kasus perzinaan yang dilakukan oleh laki-laki di Arab pada masa pra-islam merupakan tindakan wajar. Bahkan tindakan perzinaan ini menjadi simbol kejantanan sekaligus menjadi kebanggaan tersendiri bagi kaum lakilaki. ${ }^{4}$ Setelah Agama Islam masuk yang

\footnotetext{
${ }^{3}$ Mansour Fakih, Analisis Gender dan Transformasi Sosial (Yogyakarta : Pustaka Pelajar, 2008), hlm. 8

${ }^{4}$ Khairon Nahdiyyin(penj), Relasi Gender, Pada Masa Muhammad dan Khulafaurrasyidin (Yogyakarta : Pustaka Pelajar, 2007), hlm. 103
} 
dibawa oleh Nabi Muhammad, budayabudaya yang mendeskreditkan perempuan di tanah arab perlahan-perlahan dihapus. Kedatangan Nabi di tanah arab pada masa itu adalah untuk membenahi akhlak manusia. Salah satunya diwujudkan dengan mengemban tugas menjaga perempuan yang ditinggal perang suaminya melawan kaum kafir Quraisy. Secara tidak langsung, nabi telah mengupayakan menaikkan derajat perempuan di Arab agar menjadi lebih baik.

Di Indonesia sendiri yang mayoritas pendudukanya beragama Islam, posisi dan kondisi perempuan masih cukup memprihatinkan. Berbagai macam bentuk penindasan, pelecehan seksual, pemerkosaan, sub-ordinasi perempuan di berbagai bidang sampai pembunuhan masih banyak terjadi. Kebanyakan yang menjadi korban adalah kaum perempuan. Meskipun ada juga korban laki-laki namun tidak separah yang dialami oleh perempuan. Berdasarkan data yang dirilis oleh Komisi Nasional Perempuan dan Perlindungan Anak pada tahun 2017, ada 295.150 kasus kekerasan yang menimpa

\footnotetext{
${ }^{5}$ Ibid, hlm. 116-117
}

perempuan. ${ }^{6}$ Data ini menunjukan bahwa masih banyak pekerjaan yang belum diseleseikan berkaitan dengan masalah perempuan.

Dari 295.150 kasus tersebut, Provinsi Jawa Timur menempati urutan tiga besar tentang kasus perempuan. Urutan tersebut menunjukan bahwa tingkat kekerasan perempuan di Jawa Timur masih terlalu tinggi dibanding provinsi lainnya. Beberapa faktor yang menjadi penyebabnya antara lain masih kuatnya budaya patriarki sehingga laki-laki merasa lebih memiliki wewenang dibanding perempuan, ketidakseimbangan pendidikan yang diperoleh antara perempuan dengan laki-laki, dan masih menguatnya konstruksi sosial-budaya yang mendeskreditkan perempuan.

Salah satu penyumbang kasus ketidaksetaraan antara laki-laki dengan perempuan di Jawa Timur terdapat di Kabupaten Tulungagung. Kabupaten Tulungagung ini terletak di sebelah selatan Provinsi Jawa Timur. Secara geografis, Kabupaten Tulungagung di sebelah utara berbatasan dengan Kabupaten Kediri dan

${ }^{6}$ Diakses dari laman

komnasperempuan.go.id pada tanggal 02 Maret 2018 pada jam 01.45 WIB 
AGENDA : Analisis Gender dan Anak,Vol. 3 (2), 2021, (Desember)

ISSN Print: $\underline{2615-1502}$

ISSN Online: $\underline{2723-3278}$

Tersedia online di

http://ecampus.iainbatusangkar.ac.id/ojs/index.php/agenda

Kabupaten Nganjuk, di sebelah selatan berbatasan dengan Samudera Hindia, di sebelah timur berbatasan dengan Kabupaten Blitar, dan di sebelah barat berbatasan dengan Kabupaten Trenggalek dan Kabupaten Ponorogo. Kabupaten Tulungagung mempunyai jumlah penduduk 1.002.807 yang terbagi ke dalam Agama Islam (978.448 jiwa), Katolik (4.170 jiwa), Kristen (12.151 jiwa), Hindu (657 jiwa), dan Budha (1536 jiwa). ${ }^{7}$

Adapun bentuk-bentuk kekerasan yang dialami perempuan di Kabupaten Tulungagung antara lain penelantaran nafkah secara lahiriyah, ditinggal selingkuh, kekerasan seksual, dan diskriminasi yang disebabkan oleh budaya patriarki. Penelantaran nafkah secara lahiriyah disebabkan karena pengangguran laki-laki. Konsekuensinya, ekonomi dalam keluarga menjadi tidak terurus. Kemudian problem selanjutnya mengenai ditinggal selingkuh, biasanya dialami oleh perempuan yang melakukan pernikahan dini. Karena baik laki-laki dan perempuan yang usianya belum cukup untuk menikah akan mempengaruhi kondisi psikis dan

\footnotetext{
${ }^{7}$ Agus Ali Imron Al Akhyar, Moqoddimah Ngrowo, Tutur Lisan Hingga Tutur Tulisan (Yogyakarta : Deepublish, 2015), hlm. 101
}

emosi. Sehingga belum mencapai tingkat kedewasaan dalam membina rumah tangga. Terkadang problem perselingkuhan ini berujung pada perceraian.

Problem kekerasan seksual juga dialami oleh perempuan dalam bentuk kekerasan secara fisik maupun kekerasan secara kata-kata. Secara fisik misalnya dengan memperkosa, mengajak berhubungan intim di luar nikah, menyentuh bagian tubuh yang tidak dikehendaki oleh perempuan. Sedangkan kekerasan kata-kata misalnya dengan berbicara hal-hal vulgar di depan perempuan, memberikan label 'perempuan murahan', merendahkan derajat perempuan dengan bulliying.

$$
\text { Problem terakhir adalah }
$$
diskriminasi yang disebabkan oleh budaya patriarki. Di Kabupaten Tulungagung, budaya patriarki masih terasa cukup kuat. Anggapan bahwa laki-laki masih mempunyai superioritas dibanding perempuan masih mengakar kuat di masyarakat Tulungagung. Sehingga berdampak pada bidang-bidang dikehidupan masyarakat. Dibidang politik misalnya, Kabupaten Tulungagung belum 
AGENDA : Analisis Gender dan Anak,Vol. 3 (2), 2021, (Desember)

ISSN Print: $\underline{2615-1502}$

ISSN Online: $\underline{2723-3278}$

Tersedia online di

http://ecampus.iainbatusangkar.ac.id/ojs/index.php/agenda

pernah sekalipun dijabat oleh seorang bupati perempuan. ${ }^{8} \quad$ Di bidang keagamaanpun juga demikian, dominasi laki-laki terhadap perempuan masih kuat. Misalnya banyak pengurus-pengurus di masjid atau mushola yang diisi oleh lakilaki. Kalaupun ada perempuan, posisinya berada di bagian konsumsi atau dapur.

Problem tersebut bisa ditemui di desa-desa yang ada di Kabupaten Tulungagung, termasuk di Desa Kromasan. Di Desa Kromasan ini diskriminasi perempuan dalam konteks agama terjadi pada kegiatan rutinan AlBerzanji. Ada beberapa faktor yang menjadi sebab terjadinya diskriminasi perempuan dalam kegiatan Al-Berzanji.

Adapun dalam penelitian ini dibagi menjadi beberapa pokok pembahasan. Pertama meliputi sejarah dan dinamika rutinan Al-Berzanji dari masa dahulu sampai sekarang. Pembahasan ini mencoba menarasikan perkembangannya dari sisi kuantitas. Kemudian pembahasan kedua mengenai penyebab diskriminasi perempuan dalam rutinan Al-Berzanji.

Studi Kepustakaan

\footnotetext{
${ }^{8}$ Ibid hal. 89-91
}

Adapun studi pustaka yang ditemukan dari beberapa karya penelitian terdahulu yang memiliki keterkaitan dengan topik tersebut diantaranya skripsi yang ditulis oleh Ambar Rani Fauziah yang berjudul 'Diskriminasi Gender Dalam Ritual Sedekah Bumi (Analisis Gender terhadap Partisipasi Perempuan Muslim di Dusun Dungun, Kabupaten Lamongan)'.9 Skripsi tersebut membahas tentang Ritual Sedekah Bumi di Dusun Dungu yang masih mendeskreditkan perempuan. Partisipasi perempuan dalam Ritual Sedekah Bumi hanya sebagai juru masak -di bidang konsumsi- dan tidak diperbolehkan mengikuti ritual puncak Sedekah Bumi. Di dalam penelitian tersebut juga ditemukan bahwa budaya patriarki yang dilegitimasi dengan adat setempat menjadi faktor kuat terjadinya diskriminasi perempuan.

Selain itu, ada juga skripsi yang ditulis oleh Siti Khozamah yang berjudul 'Rasionalitas Dan Diskriminasi Gender Tenaga Kerja Wanita Ditinjau Dari

\footnotetext{
${ }^{9}$ Ambar Rani Fauziah, Diskriminasi Gender Dalam Ritual Sedekah Bumi ( Analisis Gender terhadap Partisipasi Perempuan Muslim di Dusun Dungun, Kabupaten Lamongan), Yogyakarta : Skripsi Fakultas Ushuluddin dan Pemikiran Islam, 2015
} 
AGENDA : Analisis Gender dan Anak,Vol. 3 (2), 2021, (Desember)

ISSN Print: $\underline{2615-1502}$

ISSN Online: $\underline{2723-3278}$

Tersedia online di

http://ecampus.iainbatusangkar.ac.id/ojs/index.php/agenda

Prespektif Teori Feminis (Studi Analisis Mantan TKW Di Desa Ratawangi, Banjarsari, Kabupaten Ciamis)'. ${ }^{10}$ Skripsi ini membahas tentang rasionalistas TKW yang belum terbentuk karena masih ada diskriminasi gender. Diskriminasi ini disebakan oleh struktur penempatan perempuan yang masih lemah, dilihat dari kacamata Marxis. Di dalam penelitian ini, perempuan didiskriminasi dalam bentuk sistem kelas. Perempuan di tempatkan di kasta kedua, setelah laki-laki.

Kemudian ada penelitian dari Mutoharoh yang berjudul 'Konstruksi Sosial Perempuan Dalam Rumah Tangga Di Banjarnegara, Jawa Tengah'. ${ }^{11}$ Penelitian ini membahas tentang ketidaksetaraan gender yang dialami oleh perempuan di RT 05 RW III daerah Sokanandi, Banjarnegara. Perempuan didiskriminasi oleh faktor budaya yang berkembang di masyarakat dengan

\footnotetext{
${ }^{10}$ Siti Khozamah, Rasionalitas Dan Diskriminasi Gender Tenaga Kerja Wanita Ditinjau Dari Perspektif Teori Feminis (Studi Analisis Mantan TKW Di Desa Ratawangi, Banjarsari, Kabupaten Ciamis), Yogyakarta : Skripsi Fakultas Ushuluddin Dan Pemikiran Islam, 2015

${ }^{11}$ Mutoharoh, "Konstruksi Sosial Perempuan Dalam Kekerasan Rumah Tangga Di Banjarnegara, Jawa Tengah", Jurnal Sosiologi Agama, Volume 10 Nomor 1, Yogyakarta : Fakultas Ushuluddin dan Pemikiran Islam, UIN Sunan Kalijaga Yogyakarta, Juni 2016
}

legitimasi agama. Dalam penelitian tersebut dijelaskan juga bahwa peran perempuan sebagai ibu ada, yakni peran biologis dan peran gender. Peran biologis seperti mengandung, menyusui, dan melahirkan. Sedangkan peran gender berupa bersih-bersih rumah, merawat dan membesarkan anak dan lain sebagainya. Namun peran gender yang berupa pekerjaan domestik dilimpahkan kepada perempuan. Jika perempuan melakukan kesalahan, maka laki-laki sebagai suami berhak untuk memberikan sanksi. Sanksi juga berlaku jika pelayanan istri tidak sesuai dengan kehendak suami.

Dari studi pustaka di atas, penelitian mengenai diskriminasi perempuan dalam konteks agama seperti di rutinan Al-Berzanji di Desa Kromasan belum pernah dilakukan. Oleh karena itu, topik ini penting untuk dikaji. Selain untuk mengetahui problem diskriminasi perempuan, topik ini juga menjadi bagian dari wacana keilmuan di era kontemporer.

\section{METODE PENELITIAN}

Penelitian ini menggunakan jenis penelitian kualitatif deskriptif. Dasar yang menjadi pertimbangannya adalah pertama, 
AGENDA : Analisis Gender dan Anak,Vol. 3 (2), 2021, (Desember)

ISSN Print: $\underline{2615-1502}$

ISSN Online: $\underline{2723-3278}$

Tersedia online di

http://ecampus.iainbatusangkar.ac.id/ojs/index.php/agenda

metode penelitian kualitatif lebih mudah disesuaikan dengan realitas yang sedang diteliti. Kedua, metode ini memberikan ruang bertemu langsung bagi peneliti untuk berinteraksi langsung dengan objek penelitian. Ketiga, metode ini lebih peka dan lebih bisa menyesuaikan pola-pola perkembangan nilai yang terjadi pada objek penelitian. ${ }^{12}$ Setelah itu, objek penelitian dijelaskan (dideskripsikan) sesuai dengan keadaan yang ada di lapangan.

Sedangkan sumber data yang digunakan dalam penelitian ini meliputi dua sumber, yakni data primer dan data sekunder. Data primer diambil dari dua unsur, yakni observasi dan wawancara. Observasi dilakukan di tempat objek yang hendak diteliti, yakni di Desa Kromasan, Kabupaten Tulungagung, Jawa Timur. Kemudian wawancara dilakukan kepada beberapa narasumber yang memiliki relevansi dengan topik penelitian. Sumber sekunder diambil dari studi kepustakaan yang meliputi akses buku-buku yang relevan dengan topik penelitian di berbagai perpustakaan di Yogyakarta. Selain itu, pencarian hasil penelitian-penelitian

12 Lexy Moleong, Metodologi Penelitian Kualitatif, (Bandung : Remaja Rosda Karya, 2000), hlm. 05 terdahulu dari berbagai jurnal yang mempunyai relevansi dengan topik penelitian.

Kondisi Geografis Desa Kromasan

Desa Kromasan terletak di Kecamatan Ngunut, Kabupaten Tulungagung. Secara geografis, Desa Kromasan di sebelah utara berbatasan dengan Desa Pulosari dan Desa Pulotondo. Di sebelah selatan berbatasan dengan Desa Purworejo. Di sebelah timur berbatasan dengan desa Purworejo dan desa Pulosari, dan di sebelah barat berbatasan dengan Desa Bendiljati Wetan yang telah masuk Kecamatan Sumbergempol.

Desa Kromasan terbagi ke dalam empat dusun, yakni Dusun Kromasan, Dusun Bakulan, Dusun Tanjung, dan Dusun Jenon. Masing-masing dusun mempunyai ciri khasnya masing-masing, Dusun Kromasan sebagai pusat desa dan dilewati jalur utama penghubung antara Desa Kromasan dengan desa-desa lainnya. Dusun Bakulan dan Dusun Tanjung merupakan basis keagamaan yang cukup kuat di Desa Kromasan. Sedangkan Dusun Jenon merupakan wilayah perekonomian desa dengan basis agraris. 
Fasilitas yang terdapat di Desa Kromasan antara lain sekolah Play Group, dua Sekolah Taman Kanak-Kanak (Dharmawanita dan Raudlatul Atfal), dua Sekolah Dasar (SDN Kromasan dan MI Kromasan), satu Sekolah Luar Biasa (SLB), lapangan sepak bola, lapangan bola voli, Kantor Balai Desa, perpustakaan masyarakat yang terletak di dalam SDN Kromasan, pondok pesantren Cangkring Ireng, dan industri makanan ringan. Di Desa Kromasan sendiri terdapat enam masjid dan tiga belas musholla, ada satu puskesmas desa yang terletak bersebelahan dengan Balai Desa. Mata pencaharian utama masyarakat di Desa Kromasan adalah bertani. Sebagian ada yang menjadi pedagang, penyedia jasa (tukang cukur rambut, tukang cuci motor), dan sebagian kecil menjadi tenaga kerja ke luar negeri. Masyarakat Desa Kromasan semuanya memeluk agama islam. Agama Islam di Desa Kromasan terbagi dalam dua kelompok, yakni islam dengan organisasi massa Nahdlatul Ulama (NU) yang menjadi mayoritas dan berpusat di Dusun Bakulan. Satunya lagi yakni Lembaga Dakwah Islam Indonesia (LDII) yang berpusat di Dusun Tanjung.
Rutinan Al-Berzanji di Desa Kromasan

Al-Berzanji mulai masuk di Desa Kromasan pada tahun 2000an. Pendirinya bernama Kang Kijon, sekaligus yang menjabat sebagai ketua pertama dari rutinan Al-Berzanji. Awal mulanya hanya sepuluh orang laki-laki yang tertarik dan mengikuti rutinan ini. Rutinan ini pada mulanya di tempatkan di masjid yang dilaksanakan pada setiap malam Minggu sehabis sholat Magrib sampai masuk waktu sholat Isya. Rutinan diakhiri dengan sholat Isya berjamaah.

Pada tahun 2002, rutinan ini banyak mendapat apresiasi yang positif dari masyarakat di Desa Kromasan. Hampir seluruh remaja laki-laki di Desa Kromasan mengikuti rutinan Al-Berzanji ini. Banyaknya remaja yang ikut membuat kewalahan Bapak Kijon untuk mengaturnya. Maka dibuatlah keliling dari satu rumah anggota ke rumah anggota lainnya. Kalau hanya terpusat di masjid, syiar Agama Islam belum ada. Selain itu, waktunya juga berubah, yang semula sehabis sholat Magrib berubah menjadi sehabis sholat Isya.

"Ya saya mendirikan Al-Berzanji ini tujuannya untuk memberikan wadah 
bagi remaja-remaja di desa ini mas. Daripada setiap malam Ahad pergi keluyuran, nongkrong di perempatan jalan yang tidak jelas itu, lebih baik kan ikut AlBerzanji ini. Awalnya saya berharap dapat menarik remaja dari desa ini lebih banyak lagi. Ya itu terkabul tahun 2002 mas."13

Rutinan Al-Berzanji ini berdiri memiliki tujuan yang positif. Setidaknya ada dua hal yang bisa diambil dari pernyataan Bapak Kijon di atas. Pertama rutinan Al-Berzanji ini difungsikan sebagai wadah remaja di Desa Kromasan. Mengingat banyak sekali tantangan yang dihadapi oleh generasi yang datang belakangan, salah satunya dalam bidang agama. Maka rutinan ini bisa menjadi salah satu media alternatif untuk membendung pengaruh negatif yang diterima oleh remaja. Kedua, rutinan AlBerzanji ini menjadi salah satu media dan upaya syiar Agama Islam di masyarakat Desa Kromasan melalui remaja-remajanya.

Pada tahun 2011, rutinan AlBerzanji yang mulanya hanya satu menjadi terbagai ke dalam empat kelompok. Dusun Tanjung, Dusun Jenon, dan Dusun Kromasan sebelah utara ada sendiritanggal 07 April 2018. sendiri. Sedangkan Dusun Kromasan sebelah selatan dan Dusun Bakulan menjadi satu rutinan Al-Berzanji. Alasan utama yang mendasari terbaginya ke dalam empat kelompok ini adalah jarak yang ditempuh terlalu jauh. Karena pada tahun tersebut, yang ikut dalam rutinan AlBerzanji tidak hanya remaja, namun anak seusia sekolah dasar dan taman kanakkanak juga ikut.

Di sisi lain, rutinan Al-Berzanji ini seleseinya juga terlalu malam. Banyak orang tua yang khawatir pada anaknya, terutama yang masih berusia sekolah dasar dan anak-anak. Sehingga pembagian menjadi empat kelompok ini tidak bisa dicegah oleh Bapak Kijon.

Akan tetapi pembagian empat kelompok rutinan Al-Berzanji ini tidak berlangsung lama. Pada tahun 2012, beberapa dusun melaksanakan rutinan AlBerzanji bersama yakni Dusun Kromasan sebelah selatan dengan Dusun Bakulan. Faktor penyebabnya adalah semakin berkurangnya kuantitas remaja yang ikut rutinan Al-Berzanji. Selain itu, pengurusnya kurang berpengalaman dalam mengelola rutinan Al-Berzanji. Sehingga rutinan Al-Berzanji jarang diselenggarakan. 
Pada tahun 2012 akhir, rutinan Al-Berzanji di Desa Kromasan menjadi satu kembali. Meskipun secara kuantitas tidak sebanyak dahulu. Waktu kegiatannya juga berubah menjadi setiap malam Jum'at setelah sholat Isya. Mulai akhir tahun tersebut, rutinan Al-Berzanji tidak setiap malam Jum'at dilaksanakan di rumah masing-masing anggota. Namun malam Jum'at pertama dan ketiga di rumah anggota masing-masing, sedangkan malam Jum'at kedua dan keempat di masjid. Pada saat jadwal di masjid digunakan untuk memperbaiki bacaan.

Di tahun selanjutnya, pembenahan-pembenahan mulai dilakukan oleh para pengurus. Salah satunya mengenai sistim pergantian ketua. Mulai tahun 2013 awal, ketua dipilih lagi secara aklamasi setelah tiga tahun mengurus dan boleh dipilih lagi selama belum menikah. Kriteria ketuanya yakni umurnya paling tua diantara anggota lainnya, tidak merangkap jabatan di organisasi lainnya, dan belum menikah.

Selain itu, rutinan Al-Berzanji di Desa Kromasan juga memiliki berbagai kegiatan. Diantaranya adalah napak tilas tokoh-tokoh agama di Kabupaten Tulungagung (ziarah), peringatan Isra'
Mi'raj Nabi Muhammad, peringatan Maulid Nabi Muhammad SAW, dan lomba-lomba pada waktu liburan sekolah. Kemudian pada waktu Idul Fitri dan Idul Adha, ada takbiran keliling bersama remaja-remaja di Desa Kromasan lainnya. Penyebab dan Bentuk Diskriminasi Perempuan Dalam Rutinan Al-Berzanji

Penyebab diskriminasi perempuan dalam rutinan Al-Berzanji ini dapat dibedakan menjadi dua faktor, yakni faktor internal dan faktor eksternal. Faktor internal berupa penilaian negatif terhadap perempuan, pembatasan ekspresi keberagamaan perempuan, dan perempuan sendiri merasa kurang berdaya. Sedangkan faktor eksternal yang menjadi sebab perempuan mendapatkan perlakuan diskriminasi pada rutinan Al-Berzanji di Desa Kromasan ada dua, pertama karena budaya patriarki yang masih mengakar kuat di masyarakat Desa Kromasan. Kedua, hampir $75 \%$ perempuan yang ada di Desa Kromasan kurang mendapatkan pendidikan yang layak. Sehingga pemikiran perempuan di Desa Kromasan kurang terbuka. Sehingga ekspresi keberagamaannya menjadi terbatas.

Rutinan Al-Berzanji di Desa Kromasan mulai awal berdiri sampai 
AGENDA : Analisis Gender dan Anak,Vol. 3 (2), 2021, (Desember)

ISSN Print: $\underline{2615-1502}$

ISSN Online: $\underline{2723-3278}$

Tersedia online di

http://ecampus.iainbatusangkar.ac.id/ojs/index.php/agenda

sekarang belum pernah melibatkan perempuan. Dalam arti melibatkan perempuan untuk ikut berpartisipasi, membaca, atau mempelajari Al-Berzanji. Jika dibandingkan dengan desa-desa di sebelah Desa Kromasan, seperti Desa Pulosari dan Desa Purworejo yang sudah melibatkan perempuan di dalam rutinan Al-Berzanji. Tidak hanya itu, bahkan beberapa perempuan di Desa Pulosari dan Desa Purworejo juga masuk dalam kepengurusan.

"Memang dari awal kita tidak pernah mengajak perempuan untuk ikut mas. Nanti malah pacaran. Tidak jadi ikut Al-Berzanji. Izinnya sama orang tua ikut Al-Berzanji, ternyata malah keluar dengan perempuan, pacaran. Untuk mengantisipasi itu, pengurus tidak mengajak perempuan untuk ikut AlBerzanji", 14

Dari pernyataan tersebut secara tidak langsung telah menunjukkan bahwa perempuan itu yang menjadi penyebab pacaran. Rutinan Al-Berzanji akan berjalan lancar jika tidak melibatkan perempuan. Stereotipe seperti di atas menjadi sebab diskriminasi perempuan

\footnotetext{
${ }^{14}$ Wawancara dengan Bapak Mashudi pada tanggal 05 April 2018.
}

dalam rutinan Al-Berzanji. Sehingga eksistensi perempuan di rutinan tersebut lebih baik ditiadakan, daripada ada kemudian membawa dampak negatif.

Selain itu, perempuan yang ikut dalam rutinan Al-Berzanji dikhawatirkan akan menyalahgunakan izin yang diberikan oleh orang tuanya. Padahal menyalahkan izin dan tidak tidak bergantung pada jenis kelamin. Laki-laki juga memiliki potensi untuk menyalahi izin. Izinnya untuk ikut rutinan AlBerzanji, malah justru digunakan untuk pacaran.

Penyebab diskriminasi lainnya yang dialami perempuan dalam rutinan AlBerzanji ini adalah adanya anggapan bahwa perempuan akan merepotkan jika dilibatkan. Karena rutinan Al-Berzanji ini seleseinya cukup larut malam. Sehingga laki-laki akan terkena beban kerja ganda. Pertama, laki-laki selalu bertugas membaca dan mempersiapkan keperluan rutinan Al-Berzanji. Kedua, laki-laki harus mengantar dan menjemput perempuan, jika perempuan dilibatkan dalam rutinan Al-Berzanji.

Penilaian negatif terhadap perempuan juga bisa dilihat dalam pernyataan Bapak Sugeng Rahayu, ketua 
AGENDA : Analisis Gender dan Anak,Vol. 3 (2), 2021, (Desember)

ISSN Print: $\underline{2615-1502}$

ISSN Online: $\underline{2723-3278}$

Tersedia online di

http://ecampus.iainbatusangkar.ac.id/ojs/index.php/agenda

Al-Berzanji Desa Kromasan pada periode 2012-2017. Padahal awalnya beliau memberikan inspirasi terhadap perempuan untuk membuat wadah sendiri yang serupa dengan rutinan Al-Berzanji.

"Lha dulu pernah tak usulin mas. Yang perempuan itu buat kelompok sendiri, kayak Al-Berzanji. Tapi khusus perempuan. Awalnya yang ikut lumayan, tapi tempatnya hanya terpusat di sini (Dusun Bakulan). Tapi hanya berjalan dua kali, lha malah bubar. Saya kurang tahu pasti mas bubarnya karena apa. Tapi semenjak itu saya kurang percaya pada perempuan jika disuruh untuk mendirikan kelompok sendiri". ${ }^{15}$

Pada mulanya ada kepercayaan bahwa perempuan mampu mendirikan rutinan yang setara dengan Al-Berzanji. Beliau memberikan usulan kepada perempuan untuk mendirikannya. Namun kepercayaan itu berubah menjadi sebuah bentuk rasa pesimis kepada perempuan ketika ada kegagalan dalam mendirikan kelompok tersebut.

Setidaknya ada dua faktor yang membuat Bapak Sugeng Rahayu jadi pesimis. Pertama dilatar belakangi dari

\footnotetext{
${ }^{15}$ Wawancara dengan Bapak Sugeng Rahayu pada tanggal 28 Maret 2018.
}

pendirian rutinan Al-Berzanji pada tahun 2000 oleh Bapak Kijon. Beliau salah satu orang pertama diantara sepuluh orang yang ikut mendirikn rutinan Al-Berzanji. Kemudian tahun 2002, kegiatan ini mendapatkan apresiasi positif oleh masyarakat di Desa Kromasan. Sehingga banyak remaja laki-laki yang berpartisipasi mengikutinya.

Faktor kedua, usulan Bapak Sugeng Rahayu tidak dibarengi dengan upaya untuk membimbing. Maka dari itu, rutinan yang didirikan oleh perempuan di Desa Kromasan hanya mampu berjalan dua kali. Saat berjalan hanya dua kali, kemudian berhenti, seharusnya Bapak Sugeng Rahayu memberikan dorongan positif agar rutinan tidak berhenti. Bukan justru berubah jadi pesimis dan menganggap bahwa perempuan tidak mampu mendirikan rutinan Al-Berzanji.

Selain itu, menurut penuturan dari Ibu Supinah, perempuan tidak perlu mengadakan dan mengikuti rutinan seperti Al-Berzanji. Karena menurutnya, rutinan seperti itu hanya pantas dilakukan oleh laki-laki. Perempuan cukup membantu memasak di dapur, ketika adiknya atau salah satu keluarganya ada yang menyelenggarakan rutinan Al-Berzanji. 
"Perempuan itu ya di dapur mas. Membantu masak jika ada kegiatan AlBerzanji. Tapi tidak perlu ikut Al-Berzanji. Yang Al-Berzanji biar laki-laki saja. Perempuan cukup membantu, jika ada salah satu keluarganya ikut AlBerzanji". ${ }^{16}$

Stereotipe yang telah tertanam, seperti penuturan Ibu Supinah bahwa perempuan cukup membantu jika ada rutinan Al-Berzanji, secara tidak langsung telah membatasi perempuan untuk mengekspresikan keberagamaannya di masyarakat. Karena, perempuan tidak diberikan ruang yang sama seperti lakilaki.

Sedangkan faktor eksternal yang melanggengkan diskriminasi terhadap perempuan pada rutinan Al-Berzanji yakni budaya patriarki yang masih mengakar kuat di masyarakat. Anggapan bahwa lakilaki memiliki posisi lebih tinggi daripada perempuan masih melekat kuat pada masyarakat di Desa Kromasan. Terbukti dengan pembatasan-pembatasan perempuan. Misalnya laki-laki diperbolehkan keluar dan pulang malam, sedangkan perempuan tidak diperbolehkan. Selain itu, posisi perempuan juga ditempatkan sebagai pendukung, bukan sebagai aktor. Misalnya perempuan hanya dilibatkan untuk membantu di dapur ketika ada anggota keluarga laki-laki yang menyelenggarakan rutinan Al-Berzanji. Perempuan tidak diberi kesempatan untuk terlibat kegiatan.

Selain itu, faktor eksternal yang menjadi sebab perempuan di Desa Kromasan terdiskriminasi dalam rutinan Al-Berzanji adalah perempuan di Desa Kromasan kurang mendapatkan pendidikan yang layak. Rata-rata perempuan di Desa Kromasan hanya sampai Sekolah Menengah Atas (SMA) dan sederajat. Setelah itu, banyak perempuan yang memilih untuk bekerja di toko, membantu orang tua, ada juga yang menikah. Hanya sebagian kecil yang melanjutkan ke perguruan tinggi atau kursus di tempat-tempat tertentu seperti menjahit, memasak, dan membuat kerajian tangan untuk menambah ketrampilan.

"Disini kebanyakan perempuannya pada bekerja mas. Kalau tidak bekerja, ya menikah. Hampir tiga per empat perempuan disini tidak melanjutkan ke 
AGENDA : Analisis Gender dan Anak,Vol. 3 (2), 2021, (Desember)

ISSN Print: $\underline{2615-1502}$

ISSN Online: $\underline{2723-3278}$

Tersedia online di

http://ecampus.iainbatusangkar.ac.id/ojs/index.php/agenda

jenjang pendidikan yang lebih tinggi, paling mentok hanya SMA mas. "17

Dari pernyataan tersebut, pendidikan juga menjadi faktor yang melanggenggkan segala bentuk budaya patriarki yang ada di Desa Kromasan. Dalam hal ini termasuk dalam konteks pada rutinan Al-Berzanji. Karena, pendidikan rendah mempunyai dampak ketidakbukaan dan ketidakkritisan perempuan. Kondisi semacam itu menjadi hal yang biasa dan lumrah dalam kehidupan sehari-hari.

\section{KESIMPULAN}

Rutinan Al-Berzanji di Desa Kromasan sudah ada sejak tahun 2000an. Rutinan tersebut mempunyai tujuan yang positif, salah satunya adalah menjadi wadah bagi remaja-remaja untuk mengekspresikan diri. Selain itu, rutinan ini juga menjadi filter bagi remaja agar tidak berbuat hal yang negatif.

Namun sepanjang perjalanannya, rutinan Al-Berzanji di Desa Kromasan belum pernah melibatkan wanita untuk turut berpartisipasi. Padahal jika dilihat dari rutinan serupa yang ada di desa-desa tetangga, misalnya Desa Pulosari dan Desa
Purworejo, perempuan telah lama dilibatkan. Tidak hanya itu, perempuan bahkan masuk dalam strutur kepengurusan.

Adapun penyebab diskriminasi perempuan dalam rutinan Al-Berzanji di Desa Kromasan yang ditemui oleh penulis bisa dipilah menjadi dua faktor, yakni faktor internal dan faktor eksternal. Faktor internal meliputi penilaian negatif terhadap perempuan, pembatasan ekspresi keberagamaan perempuan, stereotipe perempuan lekat dengan sifat lemah, subordinasi perempuan. Sedangkan faktor eksternal yang menjadi sebab perempuan mendapatkan perlakuan diskriminasi pada rutinan Al-Berzanji di Desa Kromasan ada dua, pertama karena budaya patriarki yang masih mengakar kuat di masyarakat Desa Kromasan. Kedua, hampir $75 \%$ perempuan yang ada di Desa Kromasan kurang mendapatkan pendidikan yang layak. Penyebab internal dan eksternal tersebut yang membuat perempuan didiskriminasi dalam rutinan Al-Berzanji di Desa Kromasan. 
AGENDA : Analisis Gender dan Anak,Vol. 3 (2), 2021, (Desember)

ISSN Print: $\underline{2615-1502}$

ISSN Online: $\underline{2723-3278}$

Tersedia online di

http://ecampus.iainbatusangkar.ac.id/ojs/index.php/agenda

\section{DAFTAR PUSTAKA}

Al Akhyar, Agus Ali Imron. 2015. Moqoddimah Ngrowo, Tutur Lisan Hingga Tutur Tulisan. Yogyakarta : Deepublish

Bandel, Katrin. 2016. Kajian Gender Dalam Konteks Pascakolonial. Yogyakarta : Sanata

Dharma University Press

Fakih, Mansour. 2008. Analisis Gender dan Transformasi Sosial. Yogyakarta : Pustaka Pelajar

Fauziah, Ambar Rani. 2015. Diskriminasi

Gender Dalam Ritual Sedekah Bumi

(Analisis Gender terhadap

Partisipasi Perempuan Muslim di Dusun

Dungun, Kabupaten

Lamongan). Yogyakarta : Skripsi Fakultas

Ushuluddin dan

Pemikiran Islam

Khozamah, Siti. 2015. Rasionalitas Dan

Diskriminasi Gender Tenaga Kerja

Wanita Ditinjau Dari Perspektif

Teori Feminis (Studi Analisis Mantan

TKW Di Desa Ratawangi,

Banjarsari, Kabupaten Ciamis).

Yogyakarta

: Skripsi Fakultas

Ushuluddin Dan Pemikiran Islam

Mutoharoh. Juni 2016. Konstruksi Sosial

Perempuan Dalam Kekerasan Rumah

Tangga Di Banjarnegara,

Jawa Tengah dalam Jurnal Sosiologi

Agama.

Volume 10 nomor

1. Yogyakarta : Fakultas Ushuluddin dan

Pemikiran

Islam, UIN Sunan

Kalijaga Yogyakarta

Nahdiyyin, Khairon(penj). 2007. Relasi

Gender, Pada Masa Muhammad dan

Khulafaurrasyidin. Yogyakarta :

Pustaka Pelajar
Komnasperempuan.go.id pada tanggal 02

Maret 2018 pada jam 01.45 WIB

Nasution, Harun. 1975. Pembaharuan

Dalam Islam, Sejarah Pemikiran dan

Gerakan. Jakarta : Bulan Bintang

Tim Prima Pena. 2006. Kamus

Ilmiah Populer. Gitamedia Press 